Part I. Diseases and problems distinguished by WHO and FAO

Dział I. Choroby i problemy wyróżnione przez WHO i FAO

\title{
HEALTH 2020 AND ACTION PLAN FOR PUBLIC HEALTH - NEW UNDERSTANDING OF PUBLIC HEALTH
}

\section{ZDROWIE 2020 I PLAN DZIAŁANIA W ZAKRESIE ZDROWIA PUBLICZNEGO - NOWE POJMOWANIE ZDROWIA PUBLICZNEGO}

\author{
Paulina Karwowska ${ }^{1(\mathrm{~A}, \mathrm{C}, \mathrm{D}, \mathrm{E}, \mathrm{F})}$, Weronika Gryko ${ }^{2(\mathrm{D}, \mathrm{E}, \mathrm{F})}$ \\ ${ }^{1}$ Director of the Department of the World Health Organization, Poland \\ ${ }^{2}$ University of Bologna, School of Economics, Management, and Statistics, Italy
}

Authors' contribution Wkład autorów:

A. Study design/planning zaplanowanie badań B. Data collection/entry zebranie danych

C. Data analysis/statistics dane - analiza i statystyki D. Data interpretation interpretacja danych E. Preparation of manuscript przygotowanie artykułu F. Literature analysis/search wyszukiwanie i analiza literatury G. Funds collection zebranie funduszy
Tables: 0

Figures: 0

References: 9

Submitted: 2016 Sept 12

Accepted: 2016 Oct 07

\section{Introduction}

One of the key messages of the World Health Organization (WHO) is the assumption that the health of all people, achieving peace and security all over the world and attaining the highest possible level of health are among the most fundamental human rights. This idea accompanied the creation of WHO in 1948 and was the result of over a century-long history of operations conducted by many other international organizations, which to a lesser or greater extent adopted the goal of improving health, reaching beyond the territory of one country [1]. The basic tasks of the Organization are primarily the planning and coordination of activities in all areas of health, directing research, setting norms and standards, offering the option of health policies based on knowledge and scientific evidence and direct assistance and cooperation with the member states. The support for countries in their preparations for the creation of a policy framework and strategies for health plays a key role.

The measures for the development of common guidelines for these policies gained pace particularly in the 70 s of the twentieth century, when the realization of the fundamental assumptions of WHO, stipulating the achievement of the highest attainable standard of health by all, was still a considerable distant vision. In the face of such a challenge, WHO and the member states decided to develop a framework for translating the vision of universal health for people into specific strategies and policies. This process began in 1977, when WHO and member states commenced work on the strategy "Health for All" by the year 2000 [2].

\section{The objective of this work}

The process of health policy development in the field of "Health 2020" coherent measures is part of the priority thematic scope of the journal "Health Problems of Civilization".

The aim of the study is to present the program of WHO activities in relation to the current phenomena in social, political and health prophylaxis areas, based on the monitoring of the effects of social and health phenomena, including the effects of civilizational impact.

The concept of "Health for All" was simultaneously presented in 1978 at the International Conference in Alma-Ata, devoted to primary health care. Since that time, individual countries have been encouraged and mobilized to take advantage of the assumptions of "Health for All" in formulating their national strategies. It was believed 
that translating "Health for All" into the framework of national policies within the scope including not only health, but also taking into consideration the context of the political and socioeconomic development, would have allowed for achieving the adopted goals by the year 2000.

In 1980, the European WHO Regional Committee approved the strategy "Health for All" by the year 2000, and decided to monitor its implementation and effectiveness. The specific objectives of "Health for All" were adopted in 1984 and presented a comprehensive, but also a precise vision of health development in the European Region. The strategy set out a clear framework of health policies based primarily on activities in the area of primary care, and did not focus solely on individual elements of the health system (focused mostly on the hospital sector), as was the case in the past. In order to measure progress in policy implementation and achievement of those objectives, the strategy "Health for All" established 61 indicators, with strict links to the 38 regional goals. The Developed Action Plan defined the roles and responsibilities of countries and WHO in the implementation of the strategy, while leaving plenty of room for adjustment to their national priorities. With the acceptance of these documents, the European WHO established a framework for strategy implementation, monitoring and evaluation of the progress of the undertaken measures.

In 1998, the result of the monitoring and evaluation was the decision by the European Region to revise the strategy "Health for All" and adopt the declaration "Health 21" [3]. It reflected unique changes that had occurred in Europe, including, among other things, the increase in the number of institutions involved, as well as systemic transformations and changes in the field of health caused by economic crisis. "Health 21" proposed the implementation of 21 tasks in relation to the European Region as a whole, with the assumption that they should not be equally applicable in all countries. The tasks contained in the "Health 21 " were an inspiration for individual countries to create their own specific goals. The assumptions drawn up in the Strategy were the basis for the assessment of progress in improving public health and health systems and reducing risk factors.

Updating "Health for All" in 2005, was the next step in the development of coherent health policies. Due to the changing socio-political situation and the emerging new challenges for health in the twenty-first century, Europe was in a position where it was not possible to apply a single, common solution to all countries. Constant changes in particular countries related to, among others, economic transformations and the ageing of the population contributed to the situation in which it was necessary to constantly enrich the process.

\section{'Health 2020’ policy}

In recent decades, the health level of the WHO European Region population has improved significantly. However, changing patterns of diseases, demography and migration may affect the improvement of health and require more efficient and innovative management in the health sector. In particular, this refers to the rapid increase in the incidence of chronic diseases and mental disorders, lack of social cohesion, as well as environmental risks and financial uncertainty of healthcare and social care systems. The fact that successful extension of lifespan and life in good health is enjoyed by various countries to a varying degree has become unacceptable. Many areas and social groups were left behind others, and often in the conditions of declining economy health inequalities deepened, both in separate countries and between them.

To meet these challenges, in 2012, 53 Member States of the European WHO adopted a new common policy "Health 2020: A European policy to support governments and societies for the sake of health and well-being of man" [4]. The main objectives of the strategy envisage achieving a significant improvement in the health and welfare of the population, reducing health inequalities, strengthening the public health sector, and providing highquality, universal, fair, and sustainable health systems, whose operation is focused on the human being. "Health 2020 " takes into consideration the values included in the earlier strategy of "Health for All" and constitutes a path to follow for the Member States of the WHO Regional Office for Europe.

The strategy of "Health 2020" sets two interrelated strategic objectives [5]:

1. Improving the health level of all citizens and reducing health inequalities;

2. Improving leadership and governance processes with the participation of subjects acting for health benefits.

The legitimacy of taking actions aimed at reducing health inequalities caused by socio-economic issues is founded on their proven positive impact on the health and welfare of the society. The causes of inequalities are of complex character. The difference between the longest and shortest life expectancy at birth in the WHO European Region reaches as much as 16 years. It can be also observed that there are significant persisting differences between certain countries, expressed by indicators such as infant mortality and maternal mortality. They are the result of unhealthy behaviours such as alcohol abuse, smoking, low physical activity, or mental disorders. 
Effective actions are possible only with the real involvement of all key stakeholders. More than ever before, the issue of cross-sectoral cooperation in order to implement selected policies is significant. Especially important are the programs involved in the development and health of children, creation of environments which are favourable for health-promoting behaviours and strengthening of accountable and inclusive social policies. The strategy of "Health 2020" considerably emphasizes the role of local and regional authorities, which should be particularly involved in promoting health and well-being of society. Participation, establishing responsibilities and balanced financial mechanisms reinforce the effects of such programs conducted at the local level.

In the strategy of "Health 2020" four priority action areas were specified, which were agreed by the Member States, both at the global level and after having been adapted to the specific requirements and experiences of the WHO European Region.

These measures are interrelated, interdependent and mutually supportive. They include:

1. Investment in health, based on the approach including considerations for health determinants in the life cycle and human empowering;

2. Prevention and eradication of non-communicable and infectious diseases, which pose an important health challenge in the WHO European Region;

3. Strengthening health protection systems focused on man, ability to operate and prepare for crisis situations in the field of public health, control, and response systems;

4. Building communities and environments supporting health, which are flexible and adaptive to the changing life conditions.

"Health 2020" through its adaptable and practical character constitutes a unique tool for planning and implementing health policies, taking into account different levels of experience and development of a given country.

\section{Implementation of the European Action Plan}

During the 62nd session of the World Health Organization Regional Committee for Europe (WHO EUROPE) in Malta in 2012, besides the strategy of "Health 2020" the European Action Plan for Strengthening Public Health Capacities and Services - EAP was adopted. The Action Plan was the result of extensive and long-lasting consultation between the Member States of the Region and the community of experts. The document presents the main current challenges facing public health in Europe, particularly in the face of financial and economic crisis, which has affected the financing of health policies [6]. The plan is based on the previous WHO strategies and above all on Tallinn Charter: Health Care Systems for Health and Welfare. The strategy introduces ten new revised public health functions (Essential Public Health Operations - EPHO), which are horizontal and focus on the basic public health services.

In the EAP the Acheson definition of public health was adopted: "Public health is the science and art of preventing disease, prolonging life and promoting health through the organized efforts of society". The main feature of public health is its reference to the health of the whole population. It can also be regarded as one of the main elements of the health care system. In this case, the health care system is defined as "the ensemble of all public and private organizations, institutions and resources mandated to improve, maintain or restore health. Health Care systems encompass both personal and population services, as well as activities influencing the policies and actions of other sectors influencing the social, environmental and economic determinants of health".

The implementation of the Action Plan for Strengthening the Capacity and Public Health Services required commencing discussion on the new meaning of public health in Europe. Action Plan reflects and complements rules and priorities set out in "Health 2020", which is a strategic vision of measures for the sake of health improvement in the European Region.

\section{The goal and main assumption of EAP}

The main objective of EAP is to support the Member States of the European Region in improving population health, in reducing health inequalities, in strengthening the public health capacity and the provision of basic services in terms of public health for the population, which will be of high quality and efficiency at individual and society levels [7].

The assumptions of EAP are development, implementation, monitoring and evaluation of measures strengthening public health and its capability and services through a widely-understood process of participation and consultation of all countries in the European Region and main international partners. 


\section{Essential public health operations - EPHOs}

In the process of developing the Action Plan, the key public health measures which should be the basis and guideline for countries in strengthening public health were revised and updated. It resulted primarily from transforming the health situation of societies and from changes of the public health position in the policies of the states, health ministries and local authorities. The paramount issue was the assurance of their usefulness in meeting the challenges that public health is faced with. As new, updated, basic public health measures the following were adopted:

1. Prevention and supervision of population health and its well-being;

2. Monitoring and responding in matters of health threats and crisis situations;

3. Health care including the area of the environment, work, food safety and others;

4. Health promotion including measures addressing social determinants of health and removing health inequalities;

5. Disease prevention, including early detection of diseases;

6. Ensuring management of health and well-being;

7. Ensuring sufficient and competent public health personnel;

8. Ensuring organizational structures and financing;

9. Advocacy, communication, social participation for health;

10. Progress in research on public health for policies and measures.

The first five functions consist in the provision of public health services. Functions 1 and 2 refer to information on public health, whereas functions 3 and 4 are the basic public health services such as health promotion, disease prevention and health protection in crisis situations. Other five functions (6-10) refer to strategic and cross-sectoral activities, through which it is possible to carry out the basic public health services. These measures should not be considered separately or implemented selectively. Consistency and success of public health will be achieved only when all the measures have been implemented and executed comprehensively in a permanent way. The measures envisaged in the Plan for the years 2012-2020 have been grouped in the so-called 10 avenues, which are parallel to 10 EPHOs (Essential Public Health Operations) and ensure their implementation. Each avenue contains not only an introduction to key topics, details of support, but also specific measures that will be implemented by the states, Regional Office, and other partners.

\section{Evaluating the implementation of "Health 2020"}

During the 63rd session of the Regional Committee, held in 2013, the member states adopted the resolution EUR / RC63 / R3 imposing an obligation to monitor 6 major objectives and carefully selected indicators for assessing the implementation of the "Health 2020" policy [8]. The following objectives were set:

-Reduction of premature mortality in Europe by 2020;

-Increase in life expectancy in Europe;

-Elimination of inequalities in Europe (social determinants of health);

-Improvement in the health well-being of the European population;

-Common health security and the care for citizens and their "right to health";

-Achieving national health goals set by the member states.

In addition, the countries of the European region agreed to properly monitor the implementation of the "Health 2020" policy suggested by WHO and create regular reports on the realisation of the objectives. Overall analysis and control of the implementation of this policy is conducted by the WHO Regional Director, who prepares annual reports presented to the Regional Committees and included in the subsequent scientific publications.

In 2016, the WHO Office for Europe prepared an interim report describing the implementation of the "Health 2020" policy in 2012-2016 [9]. In 2012, member states received recommendations to develop and improve their health policies, strategies and measures supporting health bearing in mind the new "Health 2020" policy assumptions. National governments should also promote the "Health 2020" policy through international cooperation, maintenance of partnership relations and cross-sectoral collaboration.

According to the report, the member states have made significant progress in implementing the "Health 2020" policy. The European region has a perfect position to reduce the number of premature deaths. However, it is an alarming fact is that the consumption of alcohol and tobacco is the highest in the world. The differences between the highest and the lowest health level determined by life expectancy and infant mortality have decreased. Despite positive changes, there are still considerable discrepancies between the member states. The main differences are evident not only in the infant mortality rates, but also in life expectancy and in the scope of social determinants of health, such as the unemployment rate. The analysis showed that health inequalities between particular countries result from social and economic reasons. 
The report from the Regional Office showed that most countries have taken determined measures for the sake of combining national health policy with the "Health 2020" framework. It was also shown that many countries had enjoyed considerable political support, received not only from the ministries of health, but also from other sectors within the implementation of the "Health 2020" policy. In most cases, the basic cross-sectoral cooperation, which opened the doors to expanded activities, was based on partnership between the health and environmental sector.

Other objectives and indicators will be defined in 2016 and described in detail during the 67th session of the Regional Committee, which will take place in 2017.

\section{Conclusion}

The World Health Organization (WHO) is a specialized international agency committed to the matters of public health, acting within United Nations System (UN). All the activities of the Organization are based on commonly recognised values. Health as a fundamental human right is recognised as the key foundation. "Health 2020" is a policy that allows to significantly improve and achieve the full health potential of societies. As part of this vision, countries should work individually and collectively to reduce inequalities in health, both within the region and outside its borders. The political commitment of governments at all levels, particularly at the local level is essential. Achieving the goals of the "Health 2020" strategy requires the integration and inclusion of various sectors and societies such as government authorities, non-governmental organisations, healthcare professionals, civic societies, the private sector, as well as scientific and academic communities.

\section{References:}

1. The Constitution of the World Health Organization as adopted by the International Health Conference, New York, 19 June - 22 July 1946; signed on 22 July 1946 by the representatives of 61 States (Official Records of the World Health Organization, no. 2, p. 100) and entered into force on 7 April 1948.

2. Global Strategy for Health for All by the Year 2000. Geneva: World Health Organization, 1981.

3. Health 21: The health for all policy framework for the WHO European Region. Copenhagen: World Health Organization Regional Office for Europe, 1999.

4. Health 2020: a European policy framework supporting action across government and society for health and well-being. Copenhagen: World Health Organization Regional Office for Europe, 2013.

5. Zdrowie 2020: Europejska polityka wspierająca działania rządów i społeczeństw na rzecz zdrowia i dobrostanu człowieka. Malta: Europejski Komitet Regionalny WHO, 62 sesja, 2012 (EUR/RC62/9).

6. European Action Plan for Strengthening Public Health Capacities and Services. Malta: Regional Committee for Europe, 62nd session, 2012 (EUR/RC62/12 Rev.1).

7. European Action Plan for Strengthening Public Health Capacities and Services. Malta: Regional Committee for Europe, 62nd session, 2012 (EUR/RC62/12 Rev.1).

8. Targets and indicators for Health 2020. Version 2. Copenhagen: WHO Regional Office for Europe, 2014.

9. Midterm progress report on Health 2020 implementation 2012-2016. Copenhagen: Regional Committee for Europe. 66th session, 2016. 